\title{
Izabela Stelmasiak
}

Akademia Pomorska

Słupsk

\section{Otoczenie polityczno-ideowe $i$ instytucjonalne czasopisma Straży Przedniej „W młodych oczach”}

Wychowanie jest dynamicznym procesem w każdym czasie, gdyż młodzież była zawsze (i jest) ważnym elementem zabiegów instrumentalnych, z manipulacjami politycznymi włącznie. Historycy, w tym historycy wychowania, są zgodni, iż istotne transformacje społeczne czy polityczne nie mogą obejść się bez udziału oraz pozyskania młodej generacji.

Zagadnienie wychowania było istotne zwłaszcza po odzyskaniu niepodległości w roku 1918, a także przez cały czas II Rzeczypospolitej. Odrębność kulturowa i gospodarcza zaborów spowodowała, że proces organizowania struktur państwowych napotykał wiele trudności. W obszarze szkolnictwa i wychowania różnice determinowane były ustrojem, sytuacją prawną oraz polityką oświatową państw zaborczych. Entuzjazm, jaki budziła możliwość wychowania młodego pokolenia w wolnej Polsce, cechował polityków wszystkich ugrupowań politycznych, zwłaszcza że wielu z nich było pedagogami lub działaczami oświatowymi. Efektem tego były rozmaite wizje szkoły i wychowania. W latach 1918-1926 dominującym kierunkiem było wychowanie narodowe, determinowane przez stanowisko Stronnictwa Narodowo-Demokratycznego ${ }^{1}$. Ikona endeków - Roman Dmowski - z antynomii naród czy państwo, za podstawową kategorię ideową uznawał naród. Naród jako grupa społeczna posiadał duszę, był bytem trwałym, ukształtowanym w kolejnych pokoleniach przez tradycję i kulturę. Państwo miało jedynie moc wykonawczą narodu. Kryterium nadrzędnym był interes i dobro narodu. Stąd zadaniem państwa było administrowanie

${ }^{1}$ Jak zauważył F. W. Araszkiewicz, w organizującym się państwie (1918-1922) zaznaczyły się dwie koncepcje ideologii wychowawczej: narodowo-chrześcijańska (endecko-chadecka) i demokratyczno-obywatelska (PPS-PSL Wyzwolenie). Wychowanie narodowe ostateczną formułę przybrało w latach 1923-1925, głównie z racji układu sił politycznych oraz sytuacji społeczno-gospodarczej Polski. F. W. Araszkiewicz, Ideały wychowawcze II Rzeczypospolitej, Warszawa 1978, s. 89-91. Reprezentanci strategii wychowania narodowego to ks. J. Gralewski, I. Moszczeńska, T. Łopuszański, B. Pręgowski, I. Pannenkowa oraz L. Zarzecki. 
wychowaniem ${ }^{2}$. Rozpatrując wychowanie w perspektywie teleologicznej, możemy stwierdzić, że endecji zależało na wychowaniu „robotników i obywateli”, ale także niwelowaniu wad narodowych, podporządkowaniu interesom całości indywidualnych interesów jednostek i grup ${ }^{3}$. Głównym celem wychowania narodowego był charakter $\mathrm{z}$ trzema składowymi - wyrobienie duchowe, rozwój samowiedzy i stosunek do rzeczywistości. Efektywnie cel ten można było osiagnąć poprzez „nauczanie, które ma znamiona pracy, będącej dla ucznia radosnym i twórczym wysiłkiem"4. Według Ireny Pannenkowej wychowanie narodowe miało być również religijne, gdyż człowiek ,życiem swoim dla Narodu i przez Naród służący i Ludzkości zarazem i Bogu"5. Pedagogika katolicka, oparta na doktrynie chrześcijańskiego personalizmu pedagogicznego, wywierała wpływ (głównie na praktykę wychowawcza) przez całe międzywojnie. Środkiem do tego prowadzącym była prasa katolicka, organizacje kościelne (Akcja Katolicka), kazania w czasie mszy świętych. Od roku 1925, zgodnie z podpisanym konkordatem, Kościół otrzymał duży wpływ na wychowanie. Zwolennicy wychowania katolickiego głosili wówczas, że

wychowanie narodowo-katolickie odbywać się winno w ramach wychowania państwowego, [...] a nauczanie dzieci i młodzieży musi opierać się na niewzruszonych fundamentach nauki Kościoła katolickiego, jego etyki, obyczajów i tradycji.

Rządy pomajowe wzmocniły jeszcze wpływ Kościoła poprzez okólnik Bartla o praktykach religijnych w szkole ${ }^{6}$. W roku 1936 na zjeździe nauczycielskim w Wilnie referat programowy Katolicka idea wychowania wygłosił czołowy teoretyk ks. K. Michalski.

Reprezentanci wychowania narodowego propagowali jednocześnie elitaryzm, gdyż przyznawali inteligencji i klasie średniej rolę przywódców. Szkołę średnią ogólnokształcąca przewidywano głównie dla tych grup, a szkoła owa miała charakter selektywny.

Dyskusje na temat ideału wychowania toczyły się na łamach prasy reprezentującej organizacje, stowarzyszenia środowiska nauczycielskiego najczęściej sympatyzujące $\mathrm{z}$ określoną stroną areny politycznej. Wobec tak złożonej rzeczywistości, środowisko nauczycielskie entuzjastycznie powitało rząd Józefa

${ }^{2}$ Tamże, s. 121; A. Friszke, O ksztalt niepodległej, Warszawa 1989, s. 100; W. Czerniewski, Z problematyki wychowawczej sanacji w okresie międzywojennym, „Nowa Szkoła” 1969, nr 4, s. 22 .

${ }^{3}$ L. Zarzecki, Wychowanie narodowe, Warszawa 1926, s. 266; R. Dmowski, Myśli nowoczesnego Polaka, Warszawa 1933, s. 2-4; F. W. Araszkiewicz, Ideały..., s. 132-138.

${ }^{4}$ F. W. Araszkiewicz, Ideały..., s. 136. Zarzecki znalazł się pod wpływem „nowego wychowania".

${ }^{5}$ I. Pannenkowa, Myśli o wychowaniu narodowym, Lwów 1918, s. 42.

${ }^{6}$ DzU Min.WriOP, 1936, nr 2, z dn. 24.04, poz. 41. 
Piłsudskiego. Załamanie społeczno-polityczne, zwrot polityczny w postaci przewrotu majowego, skutkowały realna, alternatywną wobec endeckiej ideologią wychowawczą. Wielopłaszczyznowe prace nad jej sformułowaniem toczyły się od roku 1922, choć wtedy nie była to jeszcze spójna koncepcja, ale raczej swoisty profil ideologiczny.

Po przewrocie majowym, zgodnie z towarzyszącymi mu hasłami uzdrowienia (sanacji) polityki i relacji moralnych w państwie, prace nad sformułowaniem odpowiadającej owym hasłom ideologii zostały zintensyfikowane. Zabiegi skoncentrowane były na rozbudowaniu własnego potencjału organizacyjnego oraz osłabieniu zastanego układu sił w parlamencie. Do roku 1929 Marszałkowi sprzyjała dobra koniunktura gospodarcza, a jeszcze bardziej pragnienie stabilizacji wśród społeczeństwa.

Wobec skrajnych opinii politycznych oponentów, przy relatywnie dużej sympatii społecznej dla Marszałka i ogólnej tęsknocie za stabilizacją, obóz przystapił do opracowania reprezentatywnych zasad, na które składało się:

1. Uznanie państwa za wartość nadrzędną (z pojęciem narodu włącznie) wobec innych kategorii życia;

2. Podporządkowanie państwu, jako dobru obywateli, każdej działalności publicznej;

3. Utrzymanie kultu Wodza;

4. Preferowanie elitaryzmu polegającego na stopniowaniu możliwości sprawowania władzy w zależności od zasług w twórczej pracy dla państwa oraz posiadania instynktu państwowego;

5. Odrzucenie klasycznego parlamentaryzmu;

6. Zorganizowanie państwa $\mathrm{w}$ myśl idei solidaryzmu społecznego, tak aby reprezentowało wszystkie grupy społeczne, polityczne i narodowe, które podporządkowywałyby się państwu;

7. Operowanie hasłem mocarstwowości, niwelującym historyczne kompleksy (choć w zaistniałej sytuacji gospodarczej - nieco wątpliwe) ${ }^{7}$.

Wszystkie sygnalizowane wyżej założenia determinowały poglądy na wychowanie, które po roku 1926 były alternatywne wobec wychowania narodowego endecji. W literaturze istnieje kilka określeń rozpatrywanej ideologii wychowanie państwowe, wychowanie obywatelskie, wychowanie obywatelsko-państwowe.

Ponieważ ideologia niepodległościowa miała już znaczenie historyczne, należało przekształcić ją na potrzeby „pozyskania” społeczeństwa i wychowania go dla nowego obozu. Jak zauważyła Anna Radziwiłł:

${ }^{7}$ E. Kaszuba, System propagandy państwowej obozu rzqdzqcego w Polsce w latach $1926-$ 1939, Toruń 2004, s. 172; A. Micewski, W cieniu marszałka Piłsudskiego. Szkice z dziejów myśli politycznej, Warszawa 1968, s. 338. 
program sanacji „przebudowy psychiki narodu, zmiany „duszy narodu” wychowania „nowego człowieka” czy „przebudowy patriotyzmu” to właśnie program dostosowania struktur myślenia i postaw społeczeństwa do faktu istnienia niepodległej Polski i to Polski rządzonej przez sanację ${ }^{8}$.

Forum prezentacji poglądów polityków stała się prasa codzienna oraz czasopisma adresowane do określonych odbiorców - rodziców, nauczycieli oraz młodzieży. Czasopiśmiennictwo stworzyło szczególne otoczenie i obszar towarzyszący Polakom, kształtując ich gusty, charaktery oraz ideowość. Czasopismo „Droga” (po 1926 r.) stanowiło platformę wypracowania ideologii obozu, o czym świadczy artykuł G. Linca Potrzeba rewolucji w wychowaniu, w którym autor postuluje, że po „rewolucji wojskowej” powinna nadejść rewolucja wychowania. W urabianiu człowieka zalecał wykorzystać wzorzec osobowy Wodza $^{9}$. Elżbieta Kaszuba dostrzega w nim zapowiedź klasyfikacji społeczeństwa w myśl triady: Wódz - elity - masy ${ }^{10}$. Artykuł Linca został w literaturze uznany za zaczyn sanacyjnej ideologii.

Różnorodne czasopisma, pozostające pod wpływem poszczególnych nurtów politycznych, było narzędziem eksploracji środowisk szkolnych oraz akademickich. Stanowiła ona ważki element z punktu widzenia specyficznego pisemka, jakim był organ Straży Przedniej „W młodych oczach”. Na łamach wielu podobnych periodyków pojawiały się postulaty dotyczące kwestii wychowania.

W rzeczywistości szkolnej przekonania polityczne dyrektora szkoły, nauczycieli, kleru mogły mieć decydujący wpływ na praktykę szkolną. Endecja inspirowała m. in. Towarzystwo Nauczycieli Szkół Wyższych, Stowarzyszenie Chrześcijańsko-Narodowe Nauczycielstwa Szkół Powszechnych (organy prasowe „Kwartalnik Pedagogiczny”, „Nauczyciel Polski” - eksponowały katolicki ideał wychowawczy), a także Polską Macierz Szkolną.

Forum prezentacji nowych poglądów w kwestii wychowania młodych Polaków okazał się Kongres Pedagogiczny w Poznaniu (8-10 lipca 1929 r.). W przemówieniu inaugurującym obrady zaprezentowano nowy wzór osobowy „bojownika - pracownika", który był potrzebny odrodzonemu Państwu.

Potrzebny mu jest typ obywatela, któryby dzielną pracą powszednią, ale w potrzebie i świętym zapałem walki stwierdzał swój czynny, szczery patriotyzm ${ }^{11}$.

Wytyczenie nowej busoli wychowawczej wynikało z ideologicznych priorytetów, gdyż według S. Czerwińskiego nowy kierunek nie może wynikać

${ }^{8}$ A. Radziwiłł, Ideologia wychowawcza sanacji $i$ jej odbicie $w$ polityce szkolnej $w$ latach 1926-1939, Warszawa 1966, s. 50-51 (opracowanie nieopublikowane).

${ }^{9}$ G. Linc, Potrzeba rewolucji w wychowaniu, „Droga” 1926, nr 6-7, s. 13-17.

${ }^{10}$ E. Kaszuba, System..., s. 239.

${ }^{11}$ S. Czerwiński, O nowy ideat wychowawczy, Warszawa 1930 (wyd. Zrąb), s. 43. 
ze spekulacji, czy systemu filozoficznego, ale musi wyrastać z podłoża warunków historycznych, potrzeb społecznych i prądów duchowych epoki, musi być w harmonii z tłem, do czego społeczeństwo w danym okresie dziejowym dąży, czego potrzebuje i w co wierzy ${ }^{12}$.

Nowy ideał determinowały dzieje porozbiorowe, wtedy ujawniły się zasadnicze typy psychiczne - pozytywisty i romantyka, które połączyła w wychowaniu koncepcja S. Czerwińskiego: solidna praca powszednia, a w razie potrzeby święty zapał do walki. Koncepcję tę proklamował podczas licznych spotkań ze środowiskiem nauczycielskim, gdzie przekonywał, że wychowanie państwowe mieści w sobie wychowanie narodowe. Wychowanie młodzieży do życia „dla” i „w” państwie odnosiło się również do mniejszości narodowych; uwzględniało interes Polski i obywateli mniejszości, determinowane było $\mathrm{z}$ pewnością federacyjnymi koncepcjami piłsudczyków. Wychowanie państwowe oparte było na wychowaniu religijno-moralnym, stąd zarzut o opozycję wobec Kościoła nie znajdował - według S. Czerwińskiego - podstaw. Refleksje ministra zwracały się również do uznania wzorca osobowego Józefa Piłsudskiego w procesie wychowawczym.

Proklamowana ideologia była równolegle popularyzowana $\mathrm{w}$ prasie polskiej. Organem prasowym MWRiOP był periodyk "Oświata i Wychowanie” (1929-1939). Pomijając zamieszczanie artykułów kierunkowych, stanowił on platformę dyskusyjną działaczy oświatowych ${ }^{13}$. Liczne artykuły publikowały „Droga”, krakowska „Kultura Pedagogiczna” oraz z ważniejszych - „Pion”. Sanacyjne czasopiśmiennictwo i jego rolę precyzyjnie przedstawił prof. K. Jakubiak.

Mimo różnorodnej oferty prasowej najpoważniejszą rolę w dalszym wypracowaniu i popularyzowaniu wychowania państwowego odegrała organizacja i jej organ prasowy - „Zrąb”. Inicjatorem i realizatorem obu inicjatyw był Janusz Jędrzejewicz. Celem było zorganizowanie środowiska nauczycielskiego w ruch społeczno-oświatowy, co dowodzi jego zdolności politycznych. Czasopismo stało się kontynuacją wcześniejszych inicjatyw i miejscem dalszego rozwoju umiejętności publicystycznych używanych w ,świętej sprawie".

Należy zauważyć, że sanacyjni publicyści nie uznawali wychowania państwowego za oryginalna, wyłącznie im przynależną ideologię. Odnoszono się do uwarunkowań historycznych, rozwoju teorii i praktyki europejskiego wychowa-

${ }^{12}$ AG ZNP, sygn. 1591, II kongres Pedagogiczny w Wilnie 4-8 lipca 1931, brak paginacji stron, dok. Karol Makuch, Cel i zadania szkoty polskiej. II kongres odwoływał się i kontynuował prace rozpoczęte w Poznaniu. H. Gajdamowicz, Cele wychowania na kongresach i zjazdach pedagogicznych w II Rzeczypospolitej, [w:] Kongresy i zjazdy pedagogiczne w Polsce w XX wieku, red. A. Kicowska, Toruń 2001, s. 31; F. W. Araszkiewicz, Ideaty..., s. 173-174.

${ }^{13} \mathrm{~K}$. Jakubiak, Wychowanie państwowe jako ideologia wychowawcza sanacji, Bydgoszcz 1994, s. 80-85. 
nia (lansowana szkoła pracy), eksponowano odwieczne powiązanie oświaty i wychowania z ideologia. Odpowiadała im zwłaszcza koncepcja Johna Almacka, który uznawał wychowanie moralne (ideologiczne) za jedną z czterech składowych wychowania, oprócz wiedzy ogólnej, umiejętności zawodowych, sprawności fizycznej w kontekście wzajemnych zależności, o których m. in. decyduje polityka oświatowa ${ }^{14}$. Polityka ta musiała służyć wytyczonemu celowi, tj. wychowaniu do określonego wzorca (pracownika - bojownika). Postrzegano ją jako pas transmisyjny polityki państwa w dziedzinie oświaty, przy czym ideał był jej główną składową oraz celem ${ }^{15}$. Podobnym rozumowaniem sygnalizowanych kwestii oraz retoryką posługiwał się „Zrąb”, organizacja, która po czterech latach, w roku 1934 - poza ośrodkiem warszawskim uruchomiła 76 ośrodków terenowych przynależnych do 9 sekretariatów okręgowych ${ }^{16}$. Organem prasowym organizacji był kwartalnik „Zrąb” (1930-1936) z siedzibą redakcji w Warszawie przy ul. Chmielnej 33/5, później Al. Ujazdowskie 37. Nakład pisma wynosił tysiąc egzemplarzy, miało ono objętość 160 stron, kosztowało 6 złotych za pojedynczy numer (17 zł - prenumerata roczna, 4 numery). Symboliczna była również jednolita szata graficzna czasopisma. Redaktorami naczelnymi byli Jan Dąbrowski i Janusz Jędrzejewicz. Wkrótce Jana Dąbrowskiego zastąpiła Hanna Pohoska, a Janusza Jędrzejewicza - Jan Biłek. Komitet redakcyjny złożony był z czynnych pedagogów, ideologów i działaczy sanacyjnych: prof. Stanisława Arnolda, Jana Biłka, Jana Dąbrowskiego, Janusza Jędrzejewicza, Zbigniewa Lepeckiego, Stanisława Nowakowskiego, Hanny Pohoskiej, Stanisława Podwysockiego, Ireny Posseltównej, Wandy Prażmowskiej, Jerzego Rościszewskiego, Franciszka Skibińskiego i innych. Z pismem współpracowali Jan Stanisław Bystroń, Włodzimierz Gałwecki, Aleksander Hertz, Kazimierz Kosiński, Michał Kreczmar, Jerzy Ostrowski, Adam Skwarczyński, Władysław Radziwonowicz, Józef Targowski, Józef Mirski, Czesław Znamierowski, a także autorzy zagraniczni ${ }^{17}$.

Pismo wypracowywało i upowszechniało zagadnienia wychowania państwowego, ale równocześnie pozostawiało przestrzeń na dyskusję o bieżących kwestiach spornych, organizacyjnych i wychowawczych ${ }^{18}$. Janusz Jędrzejewicz w numerze pierwszym dowodził swojej ideologicznej i politycznej proweniencji. Prezentował istotę wychowania w formule: „ukształtować człowieka, zdolnego

${ }^{14}$ J. C. Almack, Wychowanie obywatelskie, Lwów-Warszawa (b.r.w.), s. 47, [za:] B. Ługowski, Założenia..., s. 42. Odwołania historyczne ilustruje artykuł w „Drodze”: J. Husarski, Nakaz czynu majowego, „Droga” 1926, nr 6-7, s. 6-13.

${ }^{15}$ J. Husarski, Nakaz..., s. 44.

16 „Zrąb” 1933, t. XVI, s. 168; 1934, t. XVIII, s. 109; 1935, t. XXIV, s. 120.

${ }^{17}$ K. Jakubiak, Wychowanie..., s. 148.

${ }^{18}$ D. Koźmian, Janusz Jędrzejewicz polityk i pedagog (1885-1951), s. 111-112. Autorka przedstawia schemat układu treści programowych pisma. 
brać świadomie udział w społecznym życiu zbiorowości"19. Wychowanie, według Jędrzejewicza, było funkcją, a nie prekursorem życia; pojmował je jako „przygotowanie do tego życia [...], które istnieje naprawdę”. Jego zdaniem nie mogło ono polegać na ,wcielaniu w życie idealnych programów życia zbiorowego"20. Należy odnotować zatem daleko idący realizm wychowawczy autora. Ideałem był człowiek zdolny do twórczej i świadomej pracy dla Państwa. Potrafiący podporządkować swą wolę i interes społeczeństwu i państwu. Człowiek o twórczych relacjach interpersonalnych, wolnych od konfliktów narodowościowych, religijnych i klasowych. Interesującym zjawiskiem było odróżnianie przez Janusza Jędrzejewicza (do roku 1930) ideału od zagadnienia wychowawczego. Ideał zawierał światopogląd, zagadnienie wychowawcze było zaś odzwierciedleniem obiektywnego stanu rzeczy ${ }^{21}$ w Państwie - fetyszu. Był to istotny problem przy pracach ustawodawczych, zwłaszcza przy ówczesnym stosunku Kościoła do projektu. Światopogląd został tymczasowo zastapiony „wyrobieniem religijno-moralnym”, głównie zaś ideą państwa ${ }^{22}$.

Już po ogłoszeniu Ustawy... w roku 1932 „Zrąb” zamieścił artykuł pt. Epoka wielkiej reformy, w którym minister Jędrzejewicz podkreślał, że wychowanie nie było doktryną teoretyczną, lecz wynikało z rzeczywistości. Jednocześnie autor wyrażał zrębowcom wdzięczność za pomoc w pracach ustawodawczych. We wspomnieniach podkreślał, że byli oni środowiskiem, na którym mógł polegać $^{23}$. Kontynuując tradycje ,19-marcowe”, zamieszczał teksty-apoteozy na cześć Józefa Piłsudskiego, który „zniewolił współczesnych”, nauczył ich odpowiedniej ,filozofii życiowej" 24 . W ostatnim roku ukazywania się czasopisma na uwagę zasługiwała Nowa deklaracja grupy Zrab również pióra Janusza Jędrzejewicza $^{25}$. Autor widział konieczność modyfikacji ideologii i w imieniu piłsudczyków oraz zrębowców zgłaszał gotowość do wzięcia udziału w reorganizacji wychowania i ustroju. Zarówno prof. Koźmian, jak i prof. Jakubiak oceniają tę propozycję jako ,łabędzi śpiew”, „niewygodny” już w nowej rzeczywistości ${ }^{26}$.

${ }^{19}$ J. Jędrzejewicz, Wspótczesne zagadnienia wychowawcze, „Zrąb” 1930, t. I, s. 6-20. Autor podkreślał, że „twórczq treściq zagadnienia wychowawczego może być tylko Państwo”.

${ }^{20}$ J. Jędrzejewicz, Wychowanie państwowe, „Zrąb” 1930, t. III, s. 314.

${ }^{21}$ J. Jędrzejewicz, Wspótczesne..., s. 18-19. Chronologicznie pierwszy prace nad ideałem rozpoczął Kazimierz Świtalski, sformułował go Sławomir Czerwiński, a rozwinął pod nazwą zagadnienia wychowawczego i usankcjonował Ustawq... Janusz Jędrzejewicz.

${ }^{22}$ F. W. Araszkiewicz, Ideały..., s. 183.

${ }^{23}$ Przemówienie Pana Ministra WRiOP J. Jędrzejewicza, „Zrąb” 1932, t. XII, s. 64; J. Jędrzejewicz, W stużbie..., s. 160-163.

${ }^{24}$ J. Jędrzejewicz, $W$ dniu imienin, „Zrąb” 1935, t. XVIII, s. 5-7; Kronika organizacyjna Zrębu, ,Zrąb” 1930, t. I, s. 100.

${ }^{25}$ J. Jędrzejewicz, Nowa deklaracja grupy Zrab, „Zrąb” 1936, t. XXVI, s. 14.

${ }^{26}$ D. Koźmian, Janusz Jędrzejewicz..., s. 105; K. Jakubiak, Wychowanie..., s. 143-144. 
Tematyka pisma była oczywiście znacznie szersza. Poruszano zagadnienia relacji wychowania państwowego do wychowania religijnego. Autorzy, podobnie jak J. Jędrzejewicz, postrzegali wychowanie religijne jako integralny element sanacyjnego wychowania ${ }^{27}$. Zrębowcy mieli również wpływ na programy szkolne, które eksponowały wychowanie państwowe w szkołach. Projektowany przedmiot „nauka obywatelska” znalazł się jako składowa treści programowej obok języka polskiego, historii i geografii. Odrębny przedmiot „zagadnienia życia współczesnego" znalazł się w programie licealnym ${ }^{28}$. Kształcenie postaw ideowych uczniów wymagało interakcji uczniów, nauczycieli i rodziców. Do realizacji programu wychowawczego wykorzystywano organizacje i uroczystości szkolne oraz święta państwowe. Pedagogizacja rodziców służyła wprowadzaniu ideologii na grunt rodzinnego środowiska uczniów. Determinacja nauczycieli w zabiegach wychowawczych skłania dzisiaj do spostrzeżenia, iż fragmentami owe zabiegi (akademie szkolne) były propagandą, może nawet indoktrynacją ${ }^{29}$. W czasopiśmie zajmowano się również zagadnieniem polonizacji kresów wschodnich. Fundamentalne sanacyjne hasło integracji społecznej wobec ludności niepolskiej określała formuła „gente Ruthenus natione Polonus" ${ }^{30}$. Na przełomie 1931/1932 r. prezentowano aspekty reformy w zakresie strukturalnym i programowym. Później (1935 r.) ukazywano założenia Konstytucji (,Zrąb” 1935, t. 33) wraz z zawartymi tam ideami wychowawczymi (,Zrąb” 1935, t. 23). Organizacja miała dział wydawnictw, który publikował wiele czasopism oraz biblioteczkę Zrębu, adresowanych do różnych odbiorców ${ }^{31}$.

Należy uznać, że organizacja oraz kwartalnik „Zrąb” odegrały wiodącą rolę w wypracowaniu, popularyzowaniu sanacyjnej ideologii. Obrazowały historię obozu piłsudczykowskiego, ekspresję jego psychiki, a także i taktyki, głównie w obszarze wychowania. W okresie ofensywy ideologicznej (1928-1933) czołowi ideolodzy i publicyści obozu sanacyjnego (J. Jędrzejewicz, A. Skwarczyński, W. Stpiczyński) zaczęli zabiegać o poparcie i konsolidację młodzieży z obozem. Wykorzystując obecne jeszcze w pamięci rodzin polskich tradycje niepodległościowe, rozpoczęto zabiegi przygotowania młodzieży do internaliza-

${ }^{27}$ K. Jakubiak, Wychowanie..., s. 147.

${ }^{28}$ W. Garbowska, Szkolnictwo powszechne w Polsce w latach 1932-1939, Wrocław 1976, s. 81; A. Radziwiłł, Ideologia wychowawcza ..., s. 114; J. Sadowska, Ku..., s. 211.

${ }^{29}$ Archiwum Akt Nowych [dalej - AAN], sygn. 151 (B 9140), MWRiOP, Pismo min. Jędrzejewicza $w$ sprawie obchodów Święta Niepodległości, k. 48; E. Magiera, Wychowanie państwowe wszkolnictwie powszechnym Drugiej Rzeczypospolitej, Szczecin 2003, s. 205; K. Jakubiak, Współdziałanie rodziny i szkoły w pedagogice II Rzeczypospolitej, Bydgoszcz 1997, s. 210-211; M. Wójcik, Ksztaltowanie sie polskiej pedagogiki rodzinnej w latach 1918-1939, Katowice 1998, s. 73.

${ }^{30}$ J. Ostrowski, Fundamenty ideologii i próba analizy, „Zrąb” 1931, nr 5, [za:] B. Ługowski, Założenia..., s. 45 .

${ }^{31}$ B. Ługowski, Założenia ..., s. 144-160. 
cji „uzdrowionego” porządku w państwie. Służył temu ustrój szkolnictwa, który w początku sygnalizowanego okresu jeszcze ostatecznie nie okrzepł. Wspomagały to także organizacje i stowarzyszenia, choć należy zauważyć, że w przypadku młodzieży, wszelkie zabiegi były (i sa) trudne do kontrolowania i manipulacji. Wzorem stał się wówczas idealizm skautowski i harcerski obserwowany przez piłsudczyków już w czasie wojny.

Istniejące wówczas $\mathrm{w}$ Polsce organizacje i stowarzyszenia obejmowały głównie korporacje studenckie. W roku 1921 założono Związek Polskich Korporacji Akademickich pozostający pod wpływem Młodzieży Wszechpolskiej. Endeckiej proweniencji był Ruch Narodowo-Państwowy (Związek Młodych Narodowców, 1932 r.), który od roku 1934 ideowo dążył ku sanacji. W kręgach ludowych funkcjonował Centralny Związek Młodzieży Wiejskiej „Siew” (1928 r.), który po rozłamie i dalszych fuzjach z Centralnym Związkiem Młodej Wsi (1934 r.) również zyskał prosanacyjny wektor. Konserwatywny rodowód i tezy programowe cechowały Akademicką Młodzież Zachowawczą (1926 r.), która od roku 1931 nosiła nazwę Myśl Mocarstwowa - Akademicka Młodzież Państwowa (MM - AMP) $)^{32}$.

Sanacyjne projekty pozyskania młodzieży zainicjował w lutym roku 1930 Adam Skwarczyński razem z Wojciechem Stpiczyńskim i braćmi Jędrzejewiczami. W środowisku akademickim powstał wówczas Legion Młodych (LM) Akademicki Związek Pracy dla Państwa, w kręgach robotniczych jego odpowiednikiem była Organizacja Młodzieży Pracującej (od 1933 r.). Janusz Jędrzejewicz jako wiceprezes BBWR, później minister WriOP, sprawował patronat nad organizacją, choć niewątpliwie miał też swój udział w projektach i zadaniach organizacji. Stanowiły one przeciwwagę wobec wpływów Narodowej Demokracji wśród młodzieży. Legion Młodych uznawał państwo zorganizowanej pracy, aprobował kontrolę państwa nad gospodarką, produkcją oraz wolność sumienia przy uznaniu etycznej wartości religii rzymskokatolickiej. Legion był organizacją elitarną, powołaną dla zdyscyplinowanych młodych piłsudczyków, z własnym organem prasowym „Państwo Pracy”. Paradoksalnie jednak organizacja przysparzała sanatorom najwięcej problemów z powodu

\footnotetext{
${ }^{32}$ Na podstawie: E. Kaszuba, System..., s. 44-45. Z organów prasowych MM-AMP: „Buntu Młodych” oraz „Polityki” wywodzą się m. in. Jerzy Giedroyć, Adolf i Aleksander Bocheńscy, Ksawery i Mieczysław Pruszyńscy, Konstanty Łubieński, Stefan Kisielewski, Stanisław Stomma: AAN, zespół 62 BBWR, sygn. 2 (31006). Poufne pismo sekretariatu BBWR z dnia 26.06.1933 r. klasyfikuje organizacje młodzieżowe. Organizacje akademickie: prorządowe, ideowo-wychowawcze to: Legion Młodych, Zw. Polskiej Młodzieży Demokratycznej; prorządowe, korporacyjne, o charakterze klubowo-towarzyskim: Zw. Polskich Federacyj Akademickich, Blok Polskich Federacyj Akademickich. Prorządowy: Związek Strzelecki. Organizacje opozycyjne: Młodzież Wszechpolska, wchodząca w skład OWP - przyczyniła się do rozłamu Zw. Polskich Korporacyj Akademickich. Istniała także Niezależna Młodzież Socjalistyczna, która nie odgrywała większej roli. Klasyfikację i oceny studenckich stowarzyszeń katolickich zawiera: S. Gajewski, Katolickie organizacje akademickie w II Rzeczypospolitej, Lublin 1987.
} 
permanentnej ewolucji ideowej. Początkowo lewicujący, ze sztandarowym hasłem: „kto za młodu nie był socjalista, ten na starość i świnią nie będzie” (dewiza A. Skwarczyńskiego); zmieniał ideowe oblicze wraz z komendantami głównymi ${ }^{33}$. Janusz Jędrzejewicz nie poświęcił Legionowi uwagi $\mathrm{w}$ swoich wspomnieniach. Może wynikało to $\mathrm{z}$ faktu, że próba podporządkowania młodzieży poprzez LM nie zakończyła się powodzeniem. Z pewnością fakt ten determinował go do rezygnacji $\mathrm{w}$ roku $1935 \mathrm{z}$ godności seniora Legionu Młodych, o czym wspomina Bernard Singer. Deklarację o wycofaniu nazwisk z list opiekunów podpisali: J. Jędrzejewicz, W. Jędrzejewicz, W. Sławek, M. Zyndram-Kościałkowski, S. Starzyński, T. Schaetzel. Osobnym komunikatem zrzekł się senioratu K. Świtalski. Jako główny powód podano „metody daleko odbiegające od ustalonych założeń moralnych i ideowych"34. Na utratę kredytu materialnego i moralnego istotny wpływ miały różnorodne nurty zaznaczające się wewnątrz organizacji. Byli w niej fanatycy legionowej proweniencji, ale i „łowcy posad”. Marzenia o wychowaniu „paziów” Legionu Młodych, o elicie stanowiącej przyszłe rycerstwo okazały się złudne.

A. Skwarczyński był również założycielem Koła Seniorów Legionu Młodych w Warszawie, skupiającego piłsudczyków - weteranów, patronujących ideowemu kierunkowi organizacji w myśl hasła: „Legion młodych wychowuje Straż Przednią, a Straż Przednia wychowuje harcerstwo"35. O ile środowisko akademickie tworzyły osoby niezależne, starsze, które samorzutnie podejmowały działalność w organizacjach, o tyle środowisko młodzieży (głównie gimnazjalnej) nie znajdowało się (do roku 1932) pod wpływem oddziaływań piłsudczyzny. Lukę tę zlikwidował Janusz Jędrzejewicz zakładając w październiku roku 1932 Straż Przednią - Organizację Pracy Obywatelskiej, która stanowiła ofertę dla 15-21-letniej młodzieży ${ }^{36}$. Formuła ślubowania określała cel organizacji: „w imię prawa naczelnego: dobra, honoru, i potęgi Polski ślubuję Państwu Polskiemu wierną służbę, władzom organizacyjnym karność, kolegom w zespole przyjaźń i zaufanie"37. Od kandydatów nie wymagano politycznego określenia

${ }^{33}$ A. Micewski, $W$ cieniu..., s. 286-289; BN, sygn. 34240, „Gazeta Polska”, nr 15 z 15.01. 1932, s. 4, Nauczyciel i uczeń. Głos Legionu Młodych; BN, sygn. 24297, „Gazeta Polska”, nr 341 z 9.12.1934, s. 3, Legjon Młodych. Artykuł rozpatruje ferment w szeregach LM. Jednocześnie odwołuje się do genezy organizacji, czego wyrazem był protest grupy młodzieży akademickiej przeciwko nielicującym z dyscypliną żołnierską zachowaniu młodzieży endeckiej na święcie pułkowym 36. pp. w roku 1929.

${ }^{34}$ B. Singer, Od Witosa do Stawka, Paryż 1962, s. 234. Główne nurty ideowe i polityczne, płaszczyznę starć przedstawia: A. Pilch, Studencki ruch polityczny w Polsce w latach 1932-1939, „Zeszyty Naukowe Uniwersytetu Jagiellońskiego” 1972, z. 37, s. 23-48 i 129.

${ }^{35}$ K. Jakubiak, Wychowanie..., s. 174.

${ }^{36}$ Protoplastą SP były organizacje „Alfa” i „Beta”, równoważące wpływ endeckiej Narodowej Organizacji Gimnazjalnej.

${ }^{37}$ Autorem ślubowania był Adam Skwarczyński. Formuła wpisana została w książeczkę służby każdego strażowca. CAW I. 39201, Straż Przednia, Warszawa, 1938, s.18. 
się, lecz działania na rzecz budowania potęgi państwa w myśl zwrotu: „nie formuła, nie dogmat, nie hasło - lecz praca [...] z niej rodzi się w Polsce cud siły moralnej, zbiorowej, wielkość narodu"38. Organizacja strażowców („lnianych koszul") miała strukturę kadrowa, podzielona była na zespoły (jednostki pracy samokształceniowo-ideowej), które dzieliły się na koła (według zdolności, zainteresowań, aspiracji). Koła i zespoły determinowane były instrukcją Podstawy pracy $w$ zespole, autorstwa A. Skwarczyńskiego. Organizowano obozy strażowe, które były okazją do poznania nieznanych rejonów Polski, głównie zaś służyły ,pracy realizacyjnej” oraz „,samowychowawczo-ideowej”.

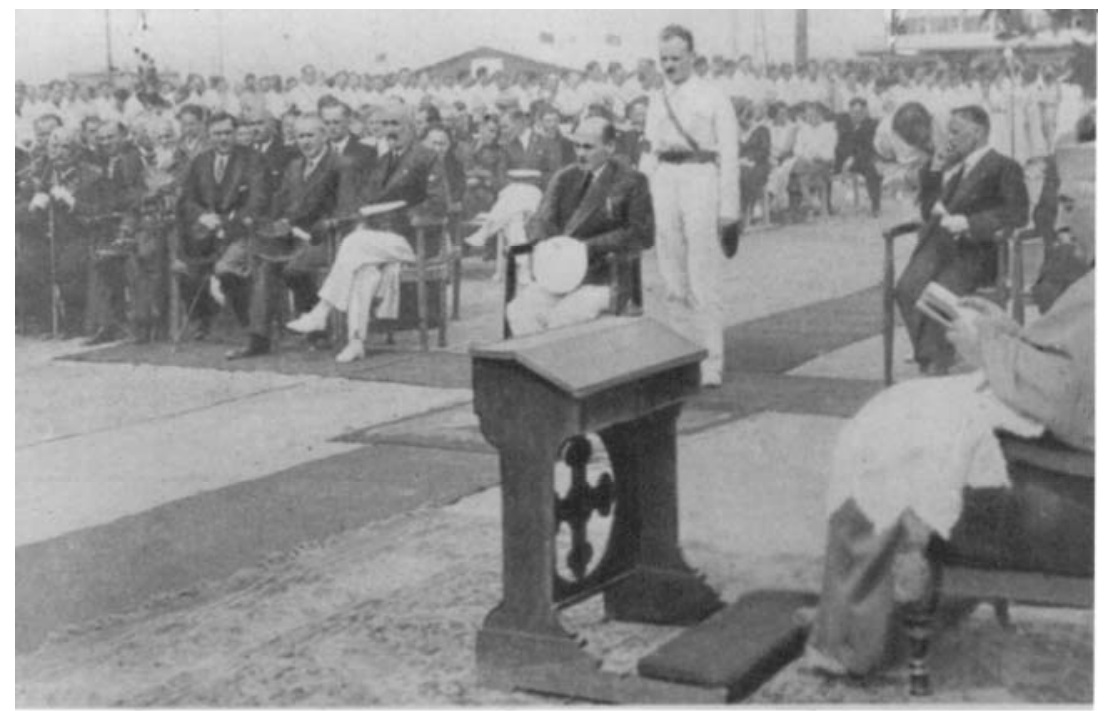

Ryc. 1. Święto Straży Przedniej z udziałem premiera J. Jędrzejewicza Źródło: CAW I. 39201, Straż Przednia

Pierwszy obóz odbył się w lecie 1933 r. i skupiał półtora tysiąca młodzieży: kolonie męskie Gdynia-Grabówek, żeńskie - Kartuzy. 22 lipca odbyło się inauguracyjne „Święto Straży Przedniej”, na którym obecny był prezydent oraz premier Janusz Jędrzejewicz. Władze odebrały „defiladę 1,5 tysiąca lnianych koszul”, przyjęły ślubowanie. Premier Jędrzejewicz podczas mszy św. wręczył naczelnikowi organizacji sztandar. Transmitowano przemówienie przez radio, premier Jędrzejewicz udzielił wywiadu radiowego, w którym wspominał swój udział w podobnej, lecz tajnej organizacji gimnazjalnej (BN, sygn. 34265, GP nr 195 z 17.07.1933, s. 1, Święto Straży Przedniej w obecności P. Prezydenta Rzplitej i p. premjera Jędrzejewicza.)

${ }^{38}$ Tamże, s. 82. Należy zauważyć, że obóz sanacyjny głosił niechęć do haseł, podobnie twierdził A. Skwarczyński w odniesieniu do młodzieży. Hasłami były dla niego imponderabilia Wodza. Równocześnie trudno zarzucić opisywanej strategii ich braku: „Tworzymy nowe Rycerstwo; bezwzględnie wykonuję to, do czego się zobowiqzałem". Ideolodzy stali jednak na stanowisku, że praca jest wartościowsza od działań doktrynerskich. Powtarzali to za J. Piłsudskim: ,w życiu wszystko się zmienia [...], a doktryny stoja w miejscu”. W. Jędrzejewicz, Kronika..., s. 403. 
Wiosną roku 1934 zmarł Adam Skwarczyński. Ostatnie pożegnanie złożył mu osobiście wieloletni towarzysz obozu peowiacko-legionowego, Janusz Jędrzejewicz, słowami: „in perpetuo frater ave”. Ostatni meldunek stanowił równocześnie podsumowanie pracy Adama Skwarczyńskiego oraz stanu Straży Przedniej w roku 1934 - 5000 młodzieży strażowej w 480 zespołach, 11 okręgowych zespołów instruktorskich. W kwietniu roku 1935 Rada Naczelna SP wybrała Janusza Jędrzejewicza na prezesa, miesiąc później przyjęto do realizacji Dekalog Strażowy będący kwintesencją sanacyjnej ideologii:

1. Straż przednia jest częścią młodej armii pracy dla P a ń s t w a oraz szkołą służby obywatelskiej młodego pokolenia.

2. Straż Przednia wychowuje młodzież przez bezpośrednią służbę Narodowi i Państwu, widząc w tej służbie najskuteczniejszą metodę kształcenia wartości moralnych, charakteru i umysłu strażowców.

3. Obowiązkiem strażowca jest dobro i honor Polski mieć ponad wszystko.

4. Wierna wskazaniom Józefa Piłsudskiego Straż Przednia widzi w czynie - sposób służby Państwu, a w pracy - sprawdzian wartości społecznych.

5. Straż Przednia opiera swą pracę na wewnętrznych nakazach moralnych i poczuciu odpowiedzialności jednostki.

6. Wywodząc się z tradycji polskiego czynu zbrojnego, Straż Przednia pielęgnuje cnoty żołnierskie i dzielność fizyczną jako rękojmię pogotowia obronnego Narodu.

7. Uważając wysoki poziom etyczny za podstawę życia zbiorowego, SP stoi na gruncie moralności chrześcijańskiej, stanowiącej podstawę kultury Narodu Polskiego.

8. Wierna tradycjom współżycia narodów Rzeczypospolitej, SP nie odtrąca nikogo, kto chce szukać duchowej łączności z Narodem polskim.

9. Obowiązkiem strażowca jest nieść czynną pomoc wszystkim, którzy jej potrzebują dając wyraz braterstwa z najszerszymi warstwami Narodu.

10. Wartość pracy strażowca mierzy się nie zakresem zadań, lecz dokładnością i sumiennością jej wykonania $^{39}$.

O stosowanie powyższych przykazań w „młodocianym czynie życia” zaapelował prezes Jędrzejewicz. Widoczne odwoływanie się do etyki chrześcijańskiej odpowiadało zapotrzebowaniu Kościoła na nadanie jej większego znaczenia w wychowaniu. Katolickiego wychowania domagał się ks. kard. Aleksander Kakowski, zwłaszcza zaś ks. kard. August Hlond. W liście pasterskim O chrześcijańskie zasady życia państwowego z kwietnia 1932 r. prymas odwoływał się do kwestii społecznych poruszanych $\mathrm{w}$ encyklikach papieskich, stanowczo przekonywał, że nienawiść wzajemna obozów politycznych ustapi pod działaniem etyki chrześcijańskiej ${ }^{40}$. Postulat wychowania Polaka-katolika towarzyszył Polakom przez całe międzywojnie.

${ }^{39}$ CAW I. 39201, k. 1; Straż..., s. 33/34. Skróty - I.S.

${ }^{40}$ F. W. Araszkiewicz, Ideaty..., s. 164-165; Ks. Kard. A. Hlond, Listy pasterskie, Poznań 1936, s. 76; BN, sygn. 34241, „Gazeta Polska”, nr 118 z 29.04.1932, s. 4, List pasterski ks. Kardynała Augusta Hlonda. 
Optymalnym miejscem do „urabiania umysłów” były organy prasowe organizacji. Legion publikował w „Echu Akademickim” (1930-1939), „Legionie Młodych” (1933-1934), „Państwie Pracy” (1933-1938), „AkademikuLegioniście” (1933-1935). Organem prasowym SP była „Kuźnia Młodych” (1932-1936), założona z inicjatywy oraz pod patronatem Adama Skwarczyńskiego, a także „W młodych oczach”.

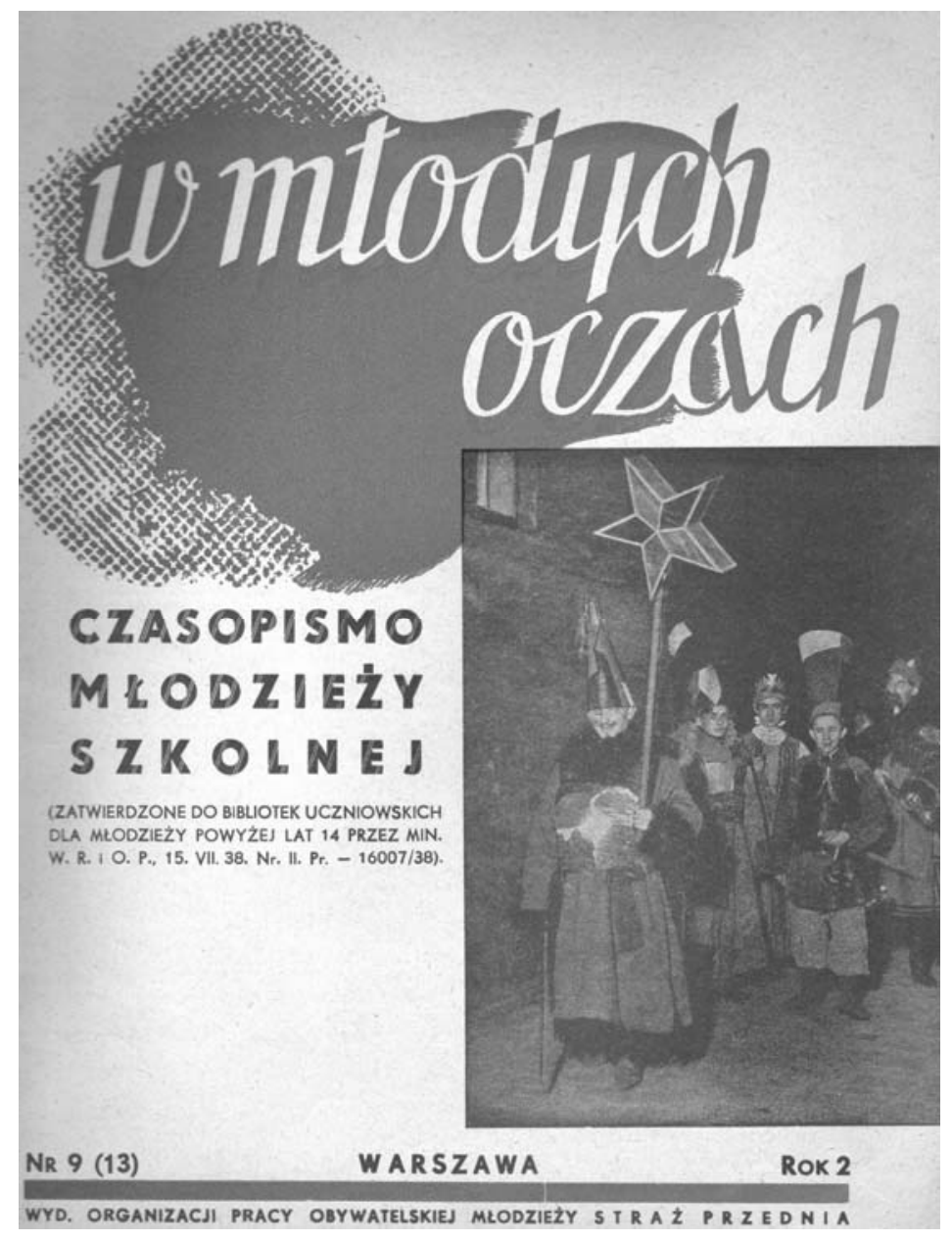

Ryc. 2. Strona tytułowa pisma młodzieży szkolnej „W młodych oczach” Czasopismo redagowane przez młodzież - członków Straży Przedniej w formie zbeletryzowanej

Czasopismo adresowane było do młodzieży szkolnej powyżej 14. roku życia. Zostało zatwierdzone do rozpowszechniania głównie w bibliotekach szkolnych przez ministra Wojciecha Świętosławskiego - Rozporzqdzeniem MWRiOP z dn. 15 lipca 1938 roku. Profil pisma mieścił się w koncepcji 
wychowawczej obywatela-żołnierza opracowanej przez urzędującego ministra prof. Świętosławskiego. Fakt ten zasługuje na uwagę z powodu niechęci do szefa resortu poprzedniego ministra, premiera J. Jędrzejewicza, który winił go za działania „na szkodę reformy” oraz „zamkową” proweniencję. Jeśli nawet realizacja kolejnych etapów reformy oświaty w obszarze programowym odbiegała od koncepcji Jędrzejewicza, to koncepcja wychowania młodzieży była kontynuowana. Świadczy o tym prezentowane pismo, którego profil zgodny był ze strategią wychowawczą ,zamkowych” piłsudczyków.

Redakcja „W młodych oczach” mieściła się przy ulicy Świętokrzyskiej 30, m. 8, sekretarzem redakcji był Czesław Domaradzki, a pismo wydawane było przez Organizację Pracy Obywatelskiej Młodzieży Straż Przednia i drukowane w Zakładach Graficzno-Introligatorskich J. Dziewulskiego przy ulicy Mariensztadt 8.

Publikowała tam młodzież licealna, która w ten sposób deklarowała „zadania strażowe" jako misję w rzeczywistości społecznej. W efekcie było to kształtowanie postaw niezbędnych w przyszłej/dorosłej odpowiedzialności społecznej. Stałe elementy pisma, redagowane przez dziennikarzy, to rubryka „wczoraj - dziś - jutro” oraz ,polityka w młodych oczach”; były one apologetyką niepodległości wraz $\mathrm{z}$ wykładnią powinności młodej generacji wobec państwa, ale i własnego wykształcenia. Interesujące są publikowane w dziale: „młode pióra" uczniowskie utwory poetyckie, podejmujące szerokie spektrum tematyki. Często były wyrazem młodzieńczej percepcji rzeczywistości wraz ze stosownymi deklaracjami:

\footnotetext{
Znowu jak na mieliźnie osiadłem na faktach,

Wśród zgiełku ulic, gdzie króluje beton,

Życie w urwanych kipi kataraktach

I dni się dłużą poetom.

$[\ldots]$

Przeorać trzeba ugory niebieskie,

Zarosłe gęstym chwastem niepamięci,

Pługiem księżyca, pługiem nowych westchnień,

Noce przeorać - na nowo uświęcićc ${ }^{41}$.
}

Na łamach pisma młodzież prezentowała działalność zespołów Straży Przedniej $\mathrm{w}$ poszczególnych placówkach szkolnych oraz $\mathrm{w}$ środowiskach lokalnych (rubryka „Wieś w Polsce”). Interesującą pozycją były „Echa z Uniwersytetu", gdzie autorzy (sygnowani jedynie inicjałami) odnosili się do zjawisk zachodzących w szkolnictwie wyższym.

Pozostałe stałe elementy pojawiające się w piśmie to:

\footnotetext{
${ }^{41}$ J. Degler, wiersz bez tytułu, „W młodych oczach” 1938, nr 9 (13), s. 6.
} 
- Kronika Strażowa - informowała o zmianach kadrowych w kierownictwie zespołów SP, o kursach, zjazdach organizowanych przez organizację, a także o nowych zarządzeniach,

- Wystawy,

- Teatr,

- Listy do Redakcji.

W czasopiśmie zamieszczane były informacje obok fotografii znanych polityków, przywódców państwa. Fotografie przedstawiały ważne osobistości z ich okresu dziecięco-młodzieżowego, pochodziły z albumów prywatnych. Umożliwiały utożsamianie się młodych członków SP z postacią i z jej dokonaniami. Prezentowano również piękno i rozwój miast Polski, zwłaszcza Warszawy. Na uwagę zasługuje fakt publikowania artykułów autorstwa uczniów z całej Polski. Pismo należy ocenić jako autentycznie redagowane i tworzone przez członków i sympatyków Straży Przedniej. Późniejsze jego losy były skutkiem sytuacji politycznej, determinującej losy organizacji młodzieżowych.

Obydwie organizacje - Legion Młodych oraz Straż Przednia - z racji środowisk, które skupiały, były czułym „barometrem politycznym”. Stanowiły naturalny element bliskiego otoczenia pisemka „W młodych oczach”. Kryzys wewnętrzny w obozie piłsudczyków - rezygnacja z haseł społecznie radykalnych - wpłynął na młodzież. W LM ujawniły się tendencje lewicowe, szczególnie po Brześciu i procesie opozycjonistów wobec sanacji. Wymienione powody determinowały treść Memoriatu do premiera Jędrzejewicza (11 października 1933 r.). Pismo wyjaśniało szereg zagadnień zilustrowanych tabelami przedstawiającymi zaangażowanie okręgów w pracy ideologicznej, pracy w BBWR, Straży Przedniej i innych ${ }^{42}$. Ówczesny Komendant Główny LM Zbigniew Zapasiewicz przekonywał premiera o jej lojalności i przydatności w pracy rządu. W celu rozpoznania rzeczywistości organizacji Ministerstwo WRiOP opracowało raport pt. Zagadnienia młodzieży w Polsce ${ }^{43}$. Dokument diagnozował ,głęboki i z trudem dający się likwidować ferment w Legionie Młodych", wytyczał zadania ośrodków dyspozycji wychowawczej - MWRiOP, wojska, MSW, MSZ, organizacji społecznych. Rok 1934 był jednak przełomowy, rozpoczynał się rozkład nawet silnych liczebnie organizacji ${ }^{44}$. Powodem niekorzystnej kondycji prosanacyjnych organizacji młodzieżowych była działalność i wpływ opozycji, zwłaszcza w środowisku akademickim. Pojawiły się dwie koncepcje, proponują-

${ }^{42}$ AAN, sygn. 25 (31078), „Legion Młodych”, k. 2-15; AAN, sygn. 153 (B 9148), „Biuletyn Prasowy Ministerstwa Wyznań Religijnych i Oświecenia Publicznego” za czas 15-25.10.1932; 8-15.03.1933; 16-22.03.1933; k. 3-8; „Biuletyn Prasowy” nr 21 i 22.

${ }^{43}$ AAN, zespół 62 BBWR, sygn. 25 (31078), Legion Młodych, s. 26-43. Problematykę młodzieży w Polsce podzielono na trzy działy: I. Kryzys metod wychowawczych, II. Próby zaprojektowania nowych metod, III. Organizacja aparatu wychowawczego.

${ }^{44}$ AIJP, Londyn, nr 26/5/3/I/12, Sytuacja polityczna w Polsce, s. 5. 
ce różne rozwiązania problemu. Pierwsza uznawała MWRiOP za naczelny państwowy ośrodek dyspozycji wychowawczej, traktując je jako autorytet formalny i moralny. W drugiej proponowano utworzenie przy Radzie Ministrów organu kierowniczo-koordynacyjnego o nazwie Komitet Wychowania Państwowego (Narodowego) ${ }^{45}$.

Ocen skuteczności strategii wychowania państwowego w kontekście organizacji młodzieżowych jest wiele. Istotę opisywanej kwestii oddał redaktor „Kuźni Młodych”, obserwator SP Kazimierz Koźniewski.

Pismo poczęte przez określony system polityczny w rezultacie wychowywało młodych ludzi przeciwko temu właśnie systemowi. Uczyło ich myśleć samodzielnie, rozsądnie, logicznie, a nie za pomocą sloganów używanych przez specjalistów od rządowej propagandy. Raz rozbudzona samodzielność intelektualna, światopoglądowa nie pozwalała zastygnąć w przewidzianym dla tej grupy schemacie sanacyjnej lewicowości. Środowisko nie było czymś autonomicznym, istniało w żywym społeczeństwie, ulegało procesom ${ }^{46}$.

Czy aż tak dalece idącą niezależność młodzieży przewidywał Janusz Jędrzejewicz - trudno ocenić, ponieważ dynamika „żywego społeczeństwa” była funkcją polityki. Radykalizacja obu organizacji sprawiała piłsudczykom coraz więcej kłopotów politycznych, czego wyraz dał sam prezydent Ignacy Mościcki, w połowie roku 1936 proklamując, że „Kuźnia Młodych” nie będzie (z tego powodu) wydawana. W tej decyzji partycypował J. Jędrzejewicz, który negatywnie recenzował pismo, przenosił jego redakcję do coraz gorszych lokali, aż doprowadził do ostatecznej likwidacji wydawnictwa.

Losy wychowania państwowego determinowane były dalszymi wydarzeniami historycznymi i ewentualnymi skutkami politycznymi. Czas po roku 1935 nie sprzyjał piłsudczykom i ich ideologii. Janusz Jędrzejewicz w związku z dekompozycją obozu odsunął się od jego prac, nie uznawał również „modyfikacji” ustroju szkolnego autorstwa min. Świętosławskiego. W ostatnim okresie II RP zauważalna była ewolucja samego ideału. Sprzyjała temu opozycja środowiska nauczycielskiego, zwłaszcza Towarzystwa Oświaty Demokratycznej „Nowe Tory”, „Miesięcznika Nauczycielskiego”. Krytyka prowadziła do nasilenia propagandy, ale równocześnie do refleksji teoretycznej nad systemami pedagogicznymi ${ }^{47}$. Wyrazem opinii środowiska pedagogów były obrady IV Kongresu Pedagogicznego (maj 1939 r.), określanego jako „kongres realistyczny”. Nie

\footnotetext{
${ }^{45}$ AAN, zespół 62 BBWR, sygn. 25 (31078), Legion Młodych, k. 43.

${ }^{46}$ K. Koźniewski, Historia co tydzień, Warszawa 1976, s. 175; M. Grzybowska, A. Skwarczyński jako ideolog wychowania młodzieży w okresie pomajowym, „Przegląd Historyczno-Oświatowy" 1983, nr 4, s. 399.

${ }^{47}$ K. Bartnicka, Wychowanie państwowe - kwestia ocen, [w:] Oświata, szkolnictwo $i$ wychowanie w latach II Rzeczpospolitej, red. K. Poznański, Lublin 1991, s. 435.
} 
negując bezpośrednio sanacyjnej strategii wychowania, uczestnicy zastapili go wzorcem żołnierza-patrioty ${ }^{48}$. Należy zauważyć, że od roku 1937 piłsudczycy proklamowali hasła „naród pod bronią” i „obywatel - żołnierz”. Przesunięcie akcentu na wychowanie społeczno-obywatelskie w rezolucji Kongresu prof. Bartnicka oceniła jako sprowadzenie czynnika państwowego do realnych rozmiarów ${ }^{49}$. Należy również zasygnalizować permanentne przenikanie idei wychowania katolickiego do państwowego, głównie poprzez działalność Akcji Katolickiej; relację hierarchów Kościoła z władzami państwowymi ${ }^{50}$.

Z pewnością wychowania państwowego w międzywojniu nie można uznać za spetryfikowaną i rutynową propozycję wychowawczą. Była ofertą determinowaną przez wstrząsy polityczne, kryzys gospodarczy, sąsiedztwo „muskularnych dyktatur". Czynniki te przekraczały zasięg i odpowiedzialność za nie sanacyjnych rządów ${ }^{51}$.

Wysiłki wychowawcze tamtego czasu trzeba jednak ocenić w kategoriach ortodoksyjnej, zbyt sztywnej wychowawczo oferty, która mimo wszystko w tamtym momencie dziejowym okazała się skuteczna i efektywna. Przekonuje dobitnie o tym pokolenie Kolumbów - rocznik 20, wychowanych w nurcie sanacyjnych zabiegów i starań pedagogicznych.

Po spadku popularności Straży Przedniej, publicystyka dokumentowała załamanie liczebności Strażowów. Co równie istotne, jakość oddziaływań wychowawczych w stopniowo odbudowywanych szeregach została utrzymana. Idee przewodnie dla otoczenia wychowanków i wychowawców proklamowała broszura 6 lat Straży Przedniej oraz książka Jędrzejewicza $W$ krainie wielkiej przygody. Składową programu odnowy młodzieżówki ortodoksyjnych piłsudczyków było niewątpliwie prezentowane pismo.

Mimo upływu czasu, transformacji ustrojowych, na podkreślenie zasługuje autentyczność pisma. Współredagowanie przez młodzież skutkowało odpowiedzialnością za poziom, obrazowało ideowość młodej generacji. Poczucie odpowiedzialności przenosiło się na inne obszary aktywności młodzieży. Porównując pismo ze współczesną ofertą czasopism dla młodzieży, należy zauważyć, iż

${ }^{48}$ Uchwaty IV Kongresu Pedagogicznego, s. 851, pkt 4; E. Magiera, Stanowisko kongresów pedagogicznych Drugiej Rzeczypospolitej wobec wychowania państwowego, [w:] Kongresy i zjazdy pedagogiczne w Polsce w XX wieku, red. A. Kicowska, Toruń 2001, s. 52-54.

${ }^{49}$ K. Bartnicka, Wychowanie państwowe, „Rozprawy z Dziejów Oświaty” 1977, t. XV, s. 127.

${ }^{50}$ K. Jakubiak, Problematyka i dorobek Zjazdów pedagogów Akcji Katolickiej w II Rzeczypospolitej, [w:] Kongresy..., s. 104-105. Wcześniej, na bazie pakietu norm prawnych reformy jędrzejewiczowskiej, starano się administracyjnie ograniczyć wpływy organizacji katolickich. Po odejściu J. Jędrzejewicza z funkcji (z urzędów) państwowych tendencja odwróciła się, a młodzież katolicka (narodowa) zyskała przewagę organizacyjną, głównie w środowisku akademickim (S. Gajewski, Katolickie organizacje..., s. 186-187 i 326).

${ }^{51} \mathrm{~K}$. Bartnicka, Wychowanie państwowe - kwestia ocen..., s. 434. 
są to głównie przedruki z pism zagranicznych. Mimo prób nie mogę doszukać się (we współczesnej ofercie prasowej) czasopisma dla młodzieży. Podejmowane w prasie młodzieżowej tematy nie kształtują gustów ani postaw czytelników. Potwierdzają jedynie, że media mogą stanowić autorytet dla oczekującego przyjemności i sensacji odbiorcy. Skutkuje to kakafonią gustów, przekonań młodej generacji oraz prowadzi do wniosku, iż współczesnym wychowawcą są Internet oraz rynek.

Czasopismo Straży Przedniej „W młodych oczach” może być przykładem pisma, które przetrwało kryzys swojego protektora - organizacji, będącej elitarną ofertą dla młodzieży. Organ prasowy współredagowany przez młodzież również trzeba zaliczyć do elitarnych. Jednak w ówczesnej sytuacji społeczno-polityczno-oświatowej był on skutecznym narzędziem wychowania i samowychowania młodej generacji. Współcześnie warto, jak sądzę, wykorzystać wiedzę o „W młodych oczach” przy podejmowaniu nowych inicjatyw i projektów wydawniczych. 